\title{
Cytokeratin expression in corneal dystrophies
}

\section{Expressão de citoqueratinas em distrofias corneanas}

\author{
Anamaria Baptista Coutinho ${ }^{1,2}$, Denise de Freitas ${ }^{1}$, João Pessoa de Souza Fillio ${ }^{1,2}$, Zélia Maria S. Corrêa ${ }^{2}$, Alexandre Nakao Odashiro ${ }^{1,2}$,
} Miguel N. Burnier JR. ${ }^{2}$

\section{ABSTRACT}

Purpose: To identify an immunohistochemical pattern of epithelial markers in granular, lattice and Avellino corneal dystrophies.

Methods: Twenty-two corneal buttons, diagnosed as lattice (17), Avellino (4) and granular (1) underwent immunohistochemical studies of cytokeratins (CKS) on paraffin-embedded sections (group I). Monoclonal antibodies for pan-CK (AE1/AE3) and $\mathrm{CKs} 3 / 12,5 / 6,8,18$ and 19 were used. Twenty-two normal corneas were used as the control (group II).

Results: Six lattice and 2 Avellino cases of group I stained positively with anti-CK $3 / 12$ in corneal epithelium and areas of corneal stroma deposits. One of these cases of lattice was positive for anti-pan-CK (AE1/AE3) also in the epithelium and areas of corneal stroma deposits with a similar pattern. None of the controls (group II) revealed any staining in corneal stroma. All disease and control cases (groups I and II) revealed positive staining in corneal epithelium.

Conclusion: AE1/AE3 and CK 3/12 anti-CK positive markers in the stromal deposits of lattice and Avellino dystrophies may suggest an epithelial genesis of the disease.

Keywords: Corneal dystrophies, hereditary; Keratins/physiology;Immunohistochemistry; Cornea/pathology

\section{RESUMO}

Objetivo: Investigar a expressão de citoqueratinas (CKS) em córneas com distrofias corneanas tipo granular, lattice e Avellino.

Métodos: Vinte e dois botões corneanos com diagnóstico anatomopatológico de distrofia estromal tipo lattice (17), Avellino (4) e granular (1) foram submetidos à avaliação imunohistoquímica nos tecidos inclusos em parafina (grupo I). Anticorpos monoclonais para pan-CK (AE1/AE3) e CKs de números 3/12, 5/6, 8, 18 e 19 foram utilizados. Vinte e dois botões corneanos normais foram usados como controle (grupo II).

Resultados: Oito casos do grupo I (seis lattice e dois Avellino) apresentaram reações imuno-histoquímicas positivas com anti-CK 3/12, tanto no epitélio como nos depósitos estromais e um destes casos (lattice) também se mostrou positivo para antipan-CK (AE1/AE3) com o mesmo padrão de reação. Nenhum caso do grupo II mostrou reação imuno-histoquímica positiva no estroma corneano. Na avaliação imuno-histoquímica dos grupos I e ll, o epitélio apresentou uma reação positiva com o anticorpo anti-pan-CK (AE1/AE3) e com o anti-CK 3/12.

Conclusão: $O$ fato da pan-CK e CK 3/12 apresentarem uma reação positiva nos depósitos das distrofias tipo lattice e Avellino sugere uma origem epitelial desses depósitos corneanos.

Descritores: Distrofias hereditárias da córnea; Queratinas/fisiologia; Imuno-histoquímica; Córnea/patologia

\section{INTRODUCTION}

The classification of primary corneal dystrophies is currently based on clinical and pathological features. The main groups have been divided, according to the location of dystrophic deposits, in epithelial and subepithelial, affecting primarily the Bowman layer, stromal, and endothelial dystrophies ${ }^{(1-2)}$.

Granular, lattice and Avellino corneal dystrophies are considered stromal diseases leading an initial assumption that the stromal keratocytes were the source of these dystrophies ${ }^{(1,3)}$. However, some investigators have suggested an epithelial rather than a stromal origin of these deposits, as their presence in the early stages and recurrences of the disease has been established in the upper microlayers of the cornea as well as the intraepithelial layers ${ }^{(3-5)}$. It has also been demonstrated that epithelial granules are similar to stromal granules in their histological staining and ultra structural features, as observed by light and electron microscopy respectively ${ }^{(5-6)}$.

The transforming growth factor beta induced gene (TGFBI) on chromosome 5, responsible for the quality and quantity of keratoepithelin, has been related to several corneal dystrophies. The immunoreactivity of the keratoepithelin protein has been demonstrated in the dystrophic deposits of corneas with granular, Avellino, Reis-Buckler, lattice and Thiel-Behnke dystrophies, all related to the TGFBl gene suggesting that keratoepithelin is a major component of these deposits ${ }^{(1,7)}$

It has also been shown that the deposits contain keratoepithelin, together with nonkeratoepithelin proteins. The inference is that mutated keratoepithelins, diffusing predominantly from the epithelium, coaggregate with an assortment of other proteins over a long period of time to form the deposits characteristic of the disorder ${ }^{(8)}$. Several substances reported to date include vimentin, immunoglobulin $\kappa$ and $\lambda$ light chains, microfibrillar protein lectinpositive carbohydrate, amyloid P protein, phospholipids, and epithelial proteins, such as the cytokeratins ${ }^{(3,7-9)}$ (Figure 1).

Cytokeratins (CKs) are water-soluble proteins found in most celltypes having characteristics of epithelial cells ${ }^{(10)}$. Among the cytokeratins, CK 3 and 12 are cornea-specific ${ }^{(11)}$. The presence of immunohistochemical markers of corneal epithelium CK in deposits of stromal dystrophies may supply an important corroboration for the hypothesis that these diseases are of epithelial origin ${ }^{(3)}$.
Funding: No specific financial support was available for this study.

Disclosure of potential conflicts of interest: A.B.Coutinho, None; D. Freitas, None; J.P.Souza Filho, None; Z.M.S.Corrêa, None; A.N.Odashiro, None; M.N.Burnier Jr, None.

Correspondence address: Anamaria Baptista Coutinho, MD, PhD. Lyman Duff Building. 3.775 University Street - Room 216 - H3A 2B4 Montreal - QC Canada

E-mail: anamariacoutinho@hotmail.com 
The goal of this investigation was to identify the immunohistochemical pattern of epithelial markers in corneal deposits of granular, lattice and Avellino dystrophies.

\section{METHODS}

Twenty-two corneal buttons were diagnosed as stromal dystrophies using H\&E, periodic acid-Schiff, Masson's trichrome, Congo red, Alcian blue and colloidal iron stains.

Immunohistochemical studies were performed on all specimens with antibodies reactive in paraffin-embedded tissue, as modified from a previously published method ${ }^{(12)}$. Peroxidase/antiperoxidase and avitin-biotin complex techniques using microwave heating were performed with monoclonal mouse antibodies for various CKs such as pan-CK (AE1/AE3), CKs 3/12, 5/6, 8, 18 and 19 $9^{(13)}$ Twenty-two, paraffin-embedded eyes enucleated due to an intraocular malignant tumor that presented normal corneas were submitted to the same process and used as controls. All primary antibodies were used in optimal dilutions, as determined by titration on positive controls, as shown in table 1.

\section{RESULTS}

\section{CoRNEAS WITH STROMAL DYSTROPHIES}

The findings observed in the stromal dystrophic corneas are summarized in table 2 . The results were analyzed separately for different areas: epithelium, stroma, endothelium, and deposits.

In all cases $(n=22)$, the corneal epithelium with dystrophies showed a positive immunostaining with anti-pan-CK (AE1/AE3) and CK 3/12. Anti-CK 18 revealed a positive reaction in almost all cases $(21 / 22)$. Anti-CK $5 / 6$ was positive in only one case and anti-CK 8 in another case. Anti-CK19 was negative in all cases $(n=22)$.

The corneal stroma of 3 cases immunoassayed positively for antiCK 3/12 (3/22) and 3 other cases were positive for anti-CK 5/6 (3/22).

The endothelium stained positively for anti-CK $3 / 12$ in all cases $(n=22)$, anti-CK 18 in 15 cases (15/22), anti-CK 8 in 3 cases (3/22) and anti-pan-CK in one case. The endothelium was negative for anti-CK $5 / 6$ and 19 in all cases.

Eight (36,3\%) corneal dystrophy cases (6 lattice and 2 Avellino) stained positively with anti-CK $3 / 12$ in corneal epithelium and areas of stroma deposits (Figures 2 A, B, C, D). One case of lattice

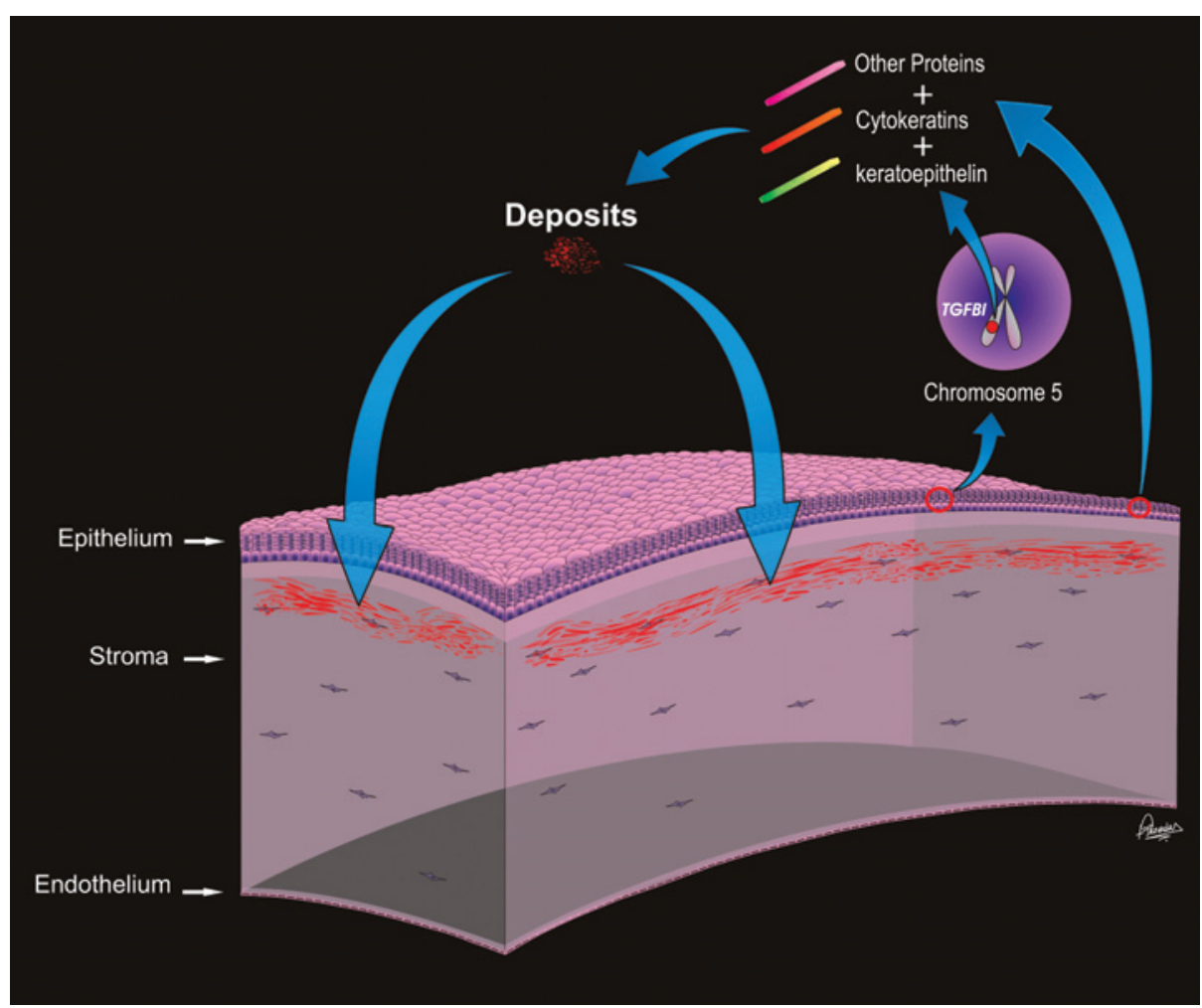

Figure 1. Schematic figure that illustrate the possible relationship between TGFBI, cytokeratin and deposits in corneal dystrophies.

Table 1. Cytokeratin primary antibodies

\begin{tabular}{lcc}
\hline Antibody & Source & Dilution \\
\hline Anti-pan CK & DakoCytomation & $1: 50$ \\
Anti-CK 3/12 & Chemicon International & $1: 50$ \\
Anti-CK 5/6 & DakoCytomation & $1: 50$ \\
Anti-CK 8 & DakoCytomation & $1: 30$ \\
Anti-CK 18 & Sigma- Aldrich & $1: 800$ \\
Anti-CK 19 & DakoCytomation & $1: 75$ \\
\hline
\end{tabular}

CK= cytokeratin 
Table 2. Cytokeratin expression in corneas with dystrophies

\begin{tabular}{|c|c|c|c|c|c|c|c|c|c|c|c|c|c|c|c|c|c|c|c|c|c|c|c|c|}
\hline \multirow[t]{2}{*}{ Case } & \multicolumn{4}{|c|}{ CK AE1 - AE3 } & \multicolumn{4}{|c|}{ CK 3/12 } & \multicolumn{4}{|c|}{ CK 5/6 } & \multicolumn{4}{|c|}{ CK 8} & \multicolumn{4}{|c|}{ CK 18} & \multicolumn{4}{|c|}{ CK 19} \\
\hline & Epi & Str & End & Dep & Epi & Str & End & Dep & Epi & Str & End & Dep & Epi & Str & End & Dep & Epi & Str & End & Dep & Epi & Str & End & Dep \\
\hline 1 & + & - & - & - & + & - & + & + & - & - & - & - & - & - & - & - & + & - & + & - & - & - & - & - \\
\hline 2 & + & - & - & - & + & + & + & - & - & - & - & - & - & - & - & - & + & - & + & - & - & - & - & - \\
\hline 3 & + & - & - & - & + & - & + & + & - & + & - & - & - & - & - & - & + & - & - & - & - & - & - & - \\
\hline 4 & + & - & - & - & + & - & + & - & - & - & - & - & - & - & - & - & + & - & + & - & - & - & - & - \\
\hline 5 & + & - & - & + & + & + & + & + & - & - & - & - & - & - & - & - & + & - & + & - & - & - & - & - \\
\hline 6 & + & - & - & - & + & - & + & - & - & - & - & - & - & - & + & - & + & - & + & - & - & - & - & - \\
\hline 7 & + & - & - & - & + & - & + & - & - & - & - & - & - & - & - & - & + & - & + & - & - & - & - & - \\
\hline 8 & + & - & - & - & + & - & + & + & - & - & - & - & + & - & - & - & + & - & + & - & - & - & - & - \\
\hline 9 & + & - & - & - & + & + & + & + & - & - & - & - & - & - & - & - & + & - & + & - & - & - & - & - \\
\hline 10 & + & - & - & - & + & - & + & - & - & - & - & - & - & - & - & - & + & - & + & - & - & - & - & - \\
\hline 11 & + & - & - & - & + & - & + & - & - & - & - & - & - & - & - & - & - & - & - & - & - & - & - & - \\
\hline 12 & + & - & - & - & + & - & + & - & - & - & - & - & - & - & - & - & + & - & - & - & - & - & - & - \\
\hline 13 & + & - & - & - & + & - & + & - & - & - & - & - & - & - & + & - & + & - & - & - & - & - & - & - \\
\hline 14 & + & - & + & - & + & - & + & - & - & - & - & - & - & - & + & - & + & - & + & - & - & - & - & - \\
\hline 15 & + & - & - & - & + & - & + & - & - & + & - & - & - & - & - & - & + & - & + & - & - & - & - & - \\
\hline 16 & + & - & - & - & + & - & + & - & - & - & - & - & - & - & - & - & + & - & - & - & - & - & - & - \\
\hline 17 & + & - & - & - & + & - & + & - & - & - & - & - & - & - & - & - & + & - & + & - & - & - & - & - \\
\hline 18 & + & - & - & - & + & - & + & - & - & - & - & - & - & - & - & - & + & - & - & - & - & - & - & - \\
\hline 19 & + & - & - & - & + & - & + & + & + & - & - & - & - & - & - & - & + & - & + & - & - & - & - & - \\
\hline 20 & + & - & - & - & + & - & + & + & - & - & - & - & - & - & - & - & + & - & + & - & - & - & - & - \\
\hline 21 & + & - & - & - & + & - & + & + & - & + & - & - & - & - & - & - & + & - & + & - & - & - & - & - \\
\hline 22 & + & - & - & - & + & - & + & - & - & - & - & - & - & - & - & - & + & - & - & - & - & - & - & - \\
\hline
\end{tabular}

$\mathrm{CK}=$ cytokeratin; Epi=epithelium; $\mathrm{Str}=$ stroma; $\mathrm{End}=$ endothelium; $\mathrm{Dep}=$ deposits

was positive for anti-pan-CK (AE1/AE3) also in the epithelium and areas of stroma deposits with a similar pattern (Figures 3 A, B, C).

\section{NORMAL CORNEAS}

The findings observed in normal corneas are summarized in table 3.

Anti-pan CK (AE1/AE3) and anti-CK 3/12 were found to be positive in the corneal epithelium of all normal cornea specimens $(n=22)$. Anti-CK 18 showed a positive staining in the majority of the cases (17/22). Anti-CK 5/6 (3/22) and anti-CK 8 (2/22) were positive in only few cases with both immune markers. Anti-CK 19 was negative in the studied cases.

The corneal stroma only showed a positive reaction for anti-CK $3 / 12$ in few cases (3/22). None of the other immune markers revealed any staining in corneal stroma.

The endothelium stained positively for anti-CK $3 / 12$ in all cases $(n=22)$, anti-CK 8 (8/22), anti-CK 18 (1/22) and anti-CK 19 (2/22). The endothelium revealed a negative reaction for anti-pan CK and antiCK $5 / 6$ in all cases.

\section{DISCUSSION}

Recent advances in the understanding of the molecular genetics and pathophysiology behind certain corneal dystrophies and the origin of the deposits has been a subject of controversial debate ${ }^{(1)}$. Earlier investigations have felt that stromal keratocytes were the source of these deposits(4). However, several lines of evidence now implicate an epithelial genesis. For example, the early stages of granular dystrophy can show fine epithelial and subepithelial deposits. As well, a superficial variant of granular dystrophy has been described; with onset in childhood, subepithelial and superficial stromal deposits and a more severe clinical course ${ }^{(5-6)}$. In addition, it has been demonstrated that while graft recurrences following penetrating keratoplasty (PK) for granular and lattice dystrophies are common and occur initially in the subepithelial region, it is only later that the stroma becomes affected $(9,14)$
The study herein has shown that the corneal deposits of lattice and Avellino dystrophies possess an immunohistochemical pattern most similar to that of the corneal epithelium, less similar to the corneal endothelium and least similar to the stroma. This assumption is due to the fact that the same proteins were found in the epithelium of all cases and in the deposits of some cases, while in the stroma they were found only in few cases, staining weakly. These findings lead us to believe that the positive anti-CK 3/12 and anti-pan CK reaction in the deposits are a strong argument against a stromal origin of these deposits. The results also speak in favour of the epithelial pathogenesis-hypothesis. A similar study with granular dystrophies has demonstrated a CK 18 expression in the corneal stroma(3).

Based on our findings, one cannot exclude the endothelial origin on these deposits although this outcome has never been reported either clinically or histologically $y^{(3-4,6,15-17)}$. On the other hand, the previously-suggested stromal hypothesis was based on the clinical and microscopic findings in advanced stages of the disease, when most of the deposits are found in the stroma. Another fact that supported this idea was the presence of granular material in membrane-bound vesicles of the keratocytes ${ }^{(17-18)}$.

The stromal theory is not necessarily incompatible with the epithelial origin of the deposits, since the deposits might have been taken up secondarily by the cells or might not be really identical to the granular deposits. However, it is also theoretically possible that both the epithelial and the stromal cells form the deposits. Perhaps the composition of these corneal deposits is complex and consists of a mixture of metabolic products from different cells, although our immunohistochemical results do not support this concept.

Another possibility is the simple mechanic adhesion effect of the antibodies in the deposits. This suggestion is improbable however, since the reactions were not homogeneously positive in all cases and were completely negative for several antibodies other than anti-CK 3/12 and anti-pan CK.

In conclusion, the fact that AE1/AE3 and CK 3/12 anti-CK markers were positive in the stromal deposits of lattice and Avellino dystrophies may suggest an epithelial origin of those corneal deposits. 
This piece of evidence may have clinical consequences and strong therapeutic implications on these diseases. Although refinements in the techniques used for transplantation and prospective, controlled studies are still necessary, limbal stem cell transplantation from a healthy donor and/or gene therapy represent possible and promising therapies for these diseases in the future.

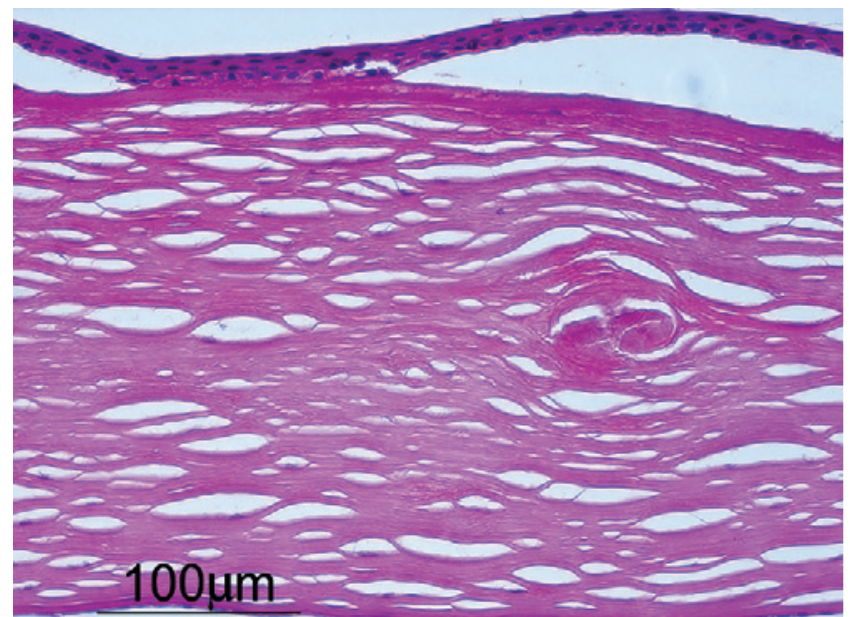

A
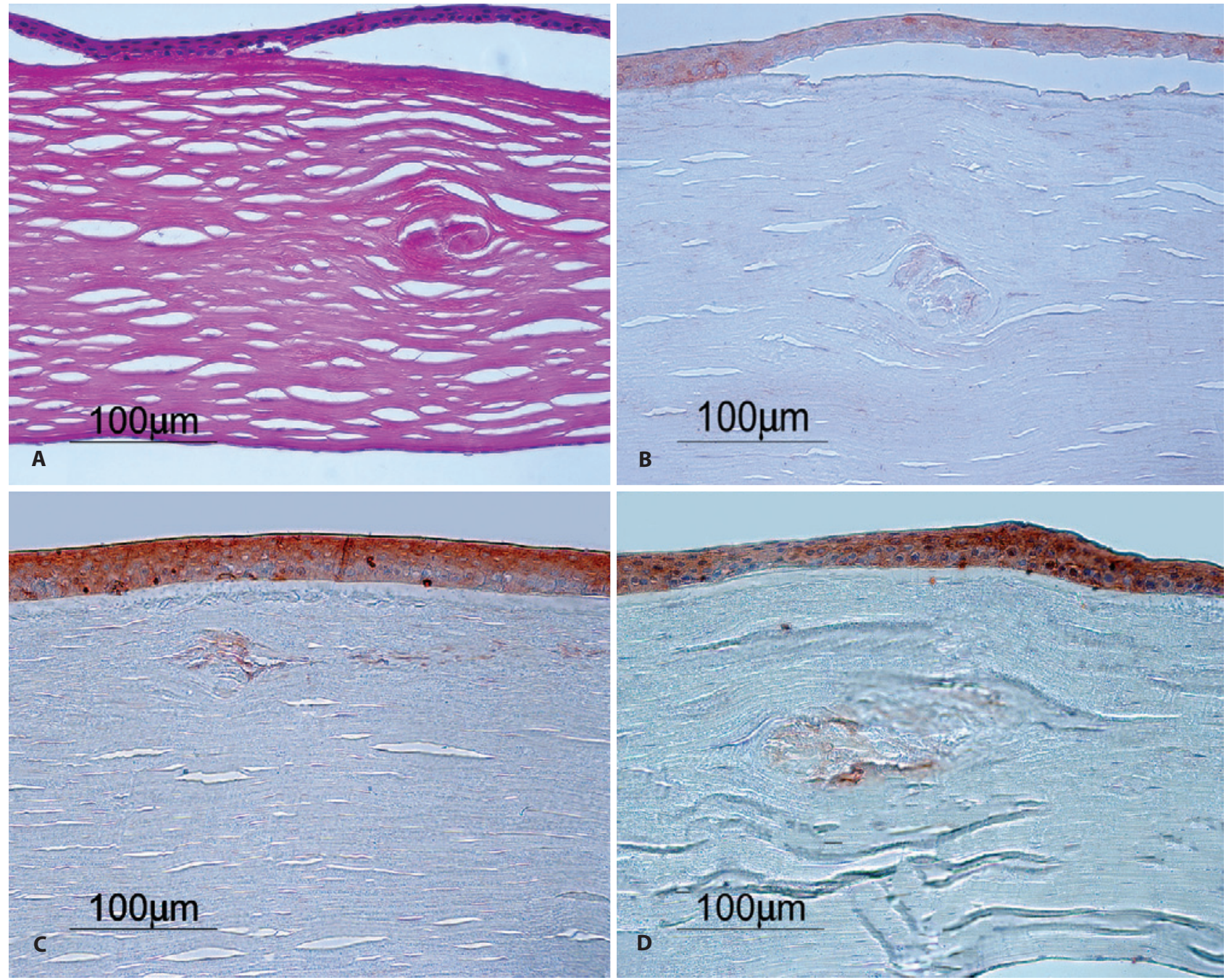

Figure 2. A) H\&E staining in a case of lattice dystrophy. (200X); B) Positive anti-CK 3/12 staining both the corneal epithelium and the deposits in the same case of lattice dystrophy. (200X); C) A case of Avellino dystrophy showing a positive anti-CK 3/12 staining of both the corneal epithelium and the deposits. (100X); D) Same case of Avellino dystrophy showing a positive anti-CK 3/12 staining of both the corneal epithelium and the deposits. (200X).
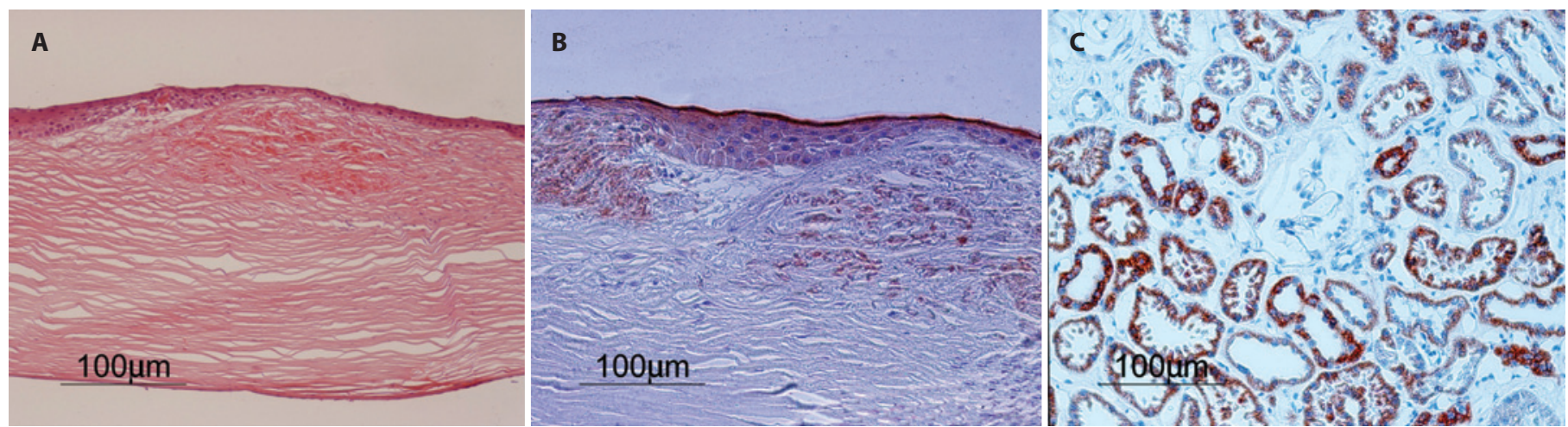

Figure 3. A) H\&E staining in a case of lattice dystrophy. (100X); B) Positive anti-pan-CK (AE1/AE3) staining both the corneal epithelium and the deposits in the same case of lattice dystrophy. (200X); C) Positive control (Kidney tubule) for anti-pan CK (AE1/AE3). (100X). 
Table 3. Cytokeratin expression in normal corneas

\begin{tabular}{|c|c|c|c|c|c|c|c|c|c|c|c|c|c|c|c|c|c|c|}
\hline \multirow[t]{2}{*}{ Case } & \multicolumn{3}{|c|}{ CK AE1 - AE3 } & \multicolumn{3}{|c|}{ CK 3/12 } & \multicolumn{3}{|c|}{ CK 5/6 } & \multicolumn{3}{|c|}{ CK 8} & \multicolumn{3}{|c|}{ CK 18} & \multicolumn{3}{|c|}{ CK 19} \\
\hline & Epi & Str & End & Epi & Str & End & Epi & Str & End & Epi & Str & End & Epi & Str & End & Epi & Str & End \\
\hline 1 & + & - & - & + & - & + & - & - & - & + & - & - & + & - & - & - & - & - \\
\hline 2 & + & - & - & + & - & + & - & - & - & - & - & - & + & - & - & - & - & + \\
\hline 3 & + & - & - & + & - & + & - & - & - & - & - & + & + & - & - & - & - & - \\
\hline 4 & + & - & - & + & - & + & - & - & - & - & - & - & + & - & - & - & - & - \\
\hline 5 & + & - & - & + & - & + & - & - & - & + & - & + & + & - & - & - & - & - \\
\hline 6 & + & - & - & + & + & + & + & - & - & - & - & - & + & - & - & - & - & - \\
\hline 7 & + & - & - & + & - & + & - & - & - & - & - & - & + & - & - & - & - & - \\
\hline 8 & + & - & - & + & - & + & - & - & - & - & - & - & + & - & - & - & - & - \\
\hline 9 & + & - & - & + & - & + & - & - & - & - & - & - & + & - & - & - & - & - \\
\hline 10 & + & - & - & + & - & + & - & - & - & - & - & - & - & - & - & - & - & - \\
\hline 11 & + & - & - & + & - & + & - & - & - & - & - & + & - & - & - & - & - & - \\
\hline 12 & + & - & - & + & - & + & - & - & - & - & - & - & + & - & - & - & - & - \\
\hline 13 & + & - & - & + & - & + & - & - & - & - & - & - & + & - & - & - & - & - \\
\hline 14 & + & - & - & + & - & + & - & - & - & - & - & + & + & - & + & - & - & + \\
\hline 15 & + & - & - & + & - & + & - & - & - & - & - & + & - & - & - & - & - & - \\
\hline 16 & + & - & - & + & + & + & + & - & - & - & - & + & + & - & - & - & - & - \\
\hline 17 & + & - & - & + & - & + & - & - & - & - & - & + & + & - & - & - & - & - \\
\hline 18 & + & - & - & + & - & + & - & - & - & - & - & + & + & - & - & - & - & - \\
\hline 19 & + & - & - & + & + & + & + & - & - & - & - & - & - & - & - & - & - & - \\
\hline 20 & + & - & - & + & - & + & - & - & - & - & - & - & + & - & - & - & - & - \\
\hline 21 & + & - & - & + & - & + & - & - & - & - & - & - & + & - & - & - & - & - \\
\hline 22 & + & - & - & + & - & + & - & - & - & - & - & - & - & - & - & - & - & - \\
\hline
\end{tabular}

CK= cytokeratin; Epi= epithelium; Str=stroma; End=endothelium

\section{REFERENCES}

1. Dunaief JL, Ng EW, Goldberg MF. Corneal dystrophies of epithelial genesis: the possible therapeutic use of limbal stem cell transplantation. Arch Ophthalmol. 2001;119(1):120-2. Comment in: Arch Ophthalmol. 2002;120(1):101.

2. Santos LN, Fernandes BF, de Moura LR, Cheema DP, Maloney S, Logan P, Burnier MN Jr. Histopathologic study of corneal stromal dystrophies: a 10-year experience. Cornea. 2007;26(9):1027-31

3. Wollensak G, Witschel H. Vimentin and cytokeratin pattern in granular corneal dystrophy. Graefes Arch Clin Exp Ophthalmol. 1996;234 Suppl 1:S110-4.

4. Witschel $H$, Sundmacher R. Bilateral recurrence of granular corneal dystrophy in the grafts. A clinico-pathologic study. Albrecht Von Graefes Arch Klin Exp Ophthalmol. 1979;209(3):179-88

5. Haddad R, Font RL, Fine BS. Unusual superficial variant of granular dystrophy of the cornea. Am J Ophthalmol. 1977;83(2):213-8.

6. Rodrigues MM, Gaster RN, Pratt MV. Unusual superficial confluent form of granular corneal dystrophy. Ophthalmology. 1983;90(12):1507-11.

7. Streeten BW, Qi Y, Klintworth GK, Eagle RC Jr, Strauss JA, Bennett K. Immunolocalization of beta ig-h3 protein in 5q31-linked corneal dystrophies and normal corneas. Arch Ophthalmol. 1999;117(1):67-75

8. Bron AJ. Genetics of the corneal dystrophies: what we have learned in the past twenty-five years. Cornea. 2000;19(5):699-711. Comment in:Cornea. 2001;20(6):672-4.

9. Akhtar S, Meek KM, Ridgway AE, Bonshek RE, Bron AJ. Deposits and proteoglycan changes in primary and recurrent granular dystrophy of the cornea. Arch Ophthalmol. 1999; 117(3):310-21.
10. Eichner R, Bonitz P, Sun TT. Classification of epidermal keratins according to their immunoreactivity, isoelectric point, and mode of expression. J Cell Biol. 1984;98(4):1388-96.

11. Cooper D, Schermer A, Sun TT. Classification of human epithelia and their neoplasms using monoclonal antibodies to keratins: strategies, applications, and limitations. Lab Invest. 1985;52(3):243-56.

12. Hsu SM, Raine L, Fanger H. Use of avidin-biotin-peroxidase complex (ABC) in immunoperoxidase techniques: a comparison between $A B C$ and unlabeled antibody (PAP) procedures. J Histochem Cytochem. 1981;29(4):577-80.

13. Cockerham GC, Laver NV, Hidayat AA, McCoy DL. An immunohistochemical analysis and comparison of posterior polymorphous dystrophy with congenital hereditary endothelial dystrophy. Cornea. 2002;21(8):787-91.

14. Garner A. Histochemistry of corneal granular dystrophy. Br J Ophthalmol. 1969;53(12): 799-807.

15. Lyons CJ, McCartney AC, Kirkness CM, Ficker LA, Steele AD, Rice NS. Granular corneal dystrophy. Visual results and pattern of recurrence after lamellar or penetrating keratoplasty. Ophthalmology. 1994;101(11):1812-7.

16. Johnson BL, Brown SI, Zaidman GW. A light and electron microscopic study of recurrent granular dystrophy of the cornea. Am J Ophthalmol. 1981;92(1):49-58.

17. Ruusuvaara P, Setälä K, Tarkkanen A. Granular corneal dystrophy with early stromal manifestation. A clinical and electron microscopical study. Acta Ophthalmol (Copenh). 1990;68(5):525-31.

18. Wittebol-Post D, van der Want JJ, van Bijsterveld OP. Granular dystrophy of the cornea (Groenouw's type I). Is the keratocyte the primary source after all? Ophthalmologica. 1987;195(4):169-77. 